\title{
Shell Band Pattern of Golden Apple Snail (Pomacea Cancaliculata, Lamarck) in Selected Aquatic Habitats
}

\author{
Gloria L. Galan, Heidi C. Porquis, and Mae Ann R. Bulasa
}

\begin{abstract}
Environmental factors affecting band patterns in the shell of Pomacea canaliculata, (Lamarck 1822) were assessed from shell samples taken in selected sites in Central Mindanao University campus, and vicinities in Bukidnon province, Philippines. Shell samples with sizes of $2 \mathrm{~cm}$ and above were used. The conchological characteristics measured were number of whorls, number of bands, width of each band, width of the shell aperture and shell length. Live weight of each individual snail was taken. The depth, temperature, pH, dissolved oxygen (DO) and salinity of water were also measured. Pearson correlation analysis shows that only variation in water depth had significant influence on the variation in the number of bands $(r=-.973, P=.01)$ and the average band width $(r=.892, P=.05)$.
\end{abstract}

Index Terms-Pomacea canaliculata, conchology, water depth.

\section{INTRODUCTION}

Interest in the golden apple snail (Pomacea canaliculata Lamarck, 1828) as a food resource and gourmet export item was noted as the basis of its introduction into the Philippines [1]. That this initiative did not succeed is a common knowledge. Facts of the invasive character of the species became evident after it was seen to cause serious damage to the rice fields following its probable escape or release into the wild [2]. The issue however is crossing national borders such that measures are taken to address the problem [3], [4].

Conchological characters in molluscs are primarily useful in identifying taxonomic groups as well as clarifying issues on populations within a given taxon [5]-[7]. However, there are findings that could show that these characters could provide visual links between environmental factors and development thus increasing understanding of a species. For instance, a study on the Roman snail (Helixpomatia) shows that heavy metal accumulation in the hepatopancreas could affect shell height, relative shell height and whorl number [8]. Other indications of environmental influence on conchological characters are shown in shell shape spectrum in Margaritiferamargaritifera $(\mathrm{L}$.) with river water $\mathrm{pH}$ and with current for Semisulcospirareinniana [9], [10]. In $P$. canaliculata, banding pattern is a conchological character

Manuscript received June 12, 2014; revised October 21, 2014. This research was funded by Central Mindanao University, Bukidnon, Philippines for the period of June 2010-February 2011.

The authors are with the Biology Department, Central Mindanao University, Bukidnon, Philippines (e-mail: dingbiocmu@yahoo.com). with ontogenetic and ecophenotypic components; attributes of the character being color, intensity, number and width of bands [11]. This study was also directed towards the same issue but in the local in situ setting. The relationship between selected environmental factors and some measurable aspects of shell band pattern in $P$. canaliculata were addressed. The empirical observations presented here might be useful as reference for future studies.

\section{Methodology}

The entry protocol was followed by an ocular inspection of the study sites: 1) Lake Napalit, 2) Lake Apo, 3) Pulangi Lake, 4) CMU PhilRice, 5) CMU fishpond, and 6) CMU Ricefield. Of these impoundments (Fig. 1-Fig. 6), only Lakes Napalit and Apo are natural formations. Two small creeks join to form the Lake Napalit tributary. The lake in turn drains into the Muleta River. Corn and sugar farmlands surround this lake as well as some trees and few small houses. For Lake Apo, the surroundings are a few households, a local tourism spot and both residual forest and planted trees. Small springs partly feed the Lake and its single outlet drains into the Pulangi River, also called the Rio Grande de Mindanao. The rest of the sampling sites are manmade impoundments. Pulangi Lake is a backflow water body resulting from the construction of the NAPOCOR hydroelectric power plant. All these are a few kilometers from the campus of Central Mindanao University in Bukidnon, Philippines. The three others, CMU PhilRice, CMU fishpond and CMU Ricefield, are within the 3,081 hectare university campus.

Water depth was measured using a meter stick; temperature with a laboratory thermometer, and $\mathrm{pH}$ with a $\mathrm{pH}$ paper and a $\mathrm{pH}$ paper standard chart for comparing color. A handheld Refractometer (Atago S/Mill-E) was used in determining salinity and the Winkler Method was followed for getting dissolved oxygen (DO).Data taken were average of three trials. On the other hand, snail samples were collected by hand picking. An arbitrary lower limit of size for samples collected was about $2 \mathrm{~cm}$. to exclude juveniles. Data collection in all sites including snail sampling was only within a distance of one (1) meter from the shoreline.

Collections were placed in properly labeled plastic bags. Subsequent processing of the specimens included boiling for easy meat extraction, and cleaning of the shell. Protective gloves were used. Morphometric data (Fig. 7-Fig. 10) to characterize shell band pattern included shell length, width of the aperture, band width per shell, number of bands, and number of whorls. Measurements were to the nearest millimeter $(\mathrm{mm})$. All bands in each collected shell were 
measured. Individual weights of live snails were also recorded. Two sampling visits were made per site for the period of June 2010 to February 2011. Twenty (20) samples were randomly collected from each station per visit.

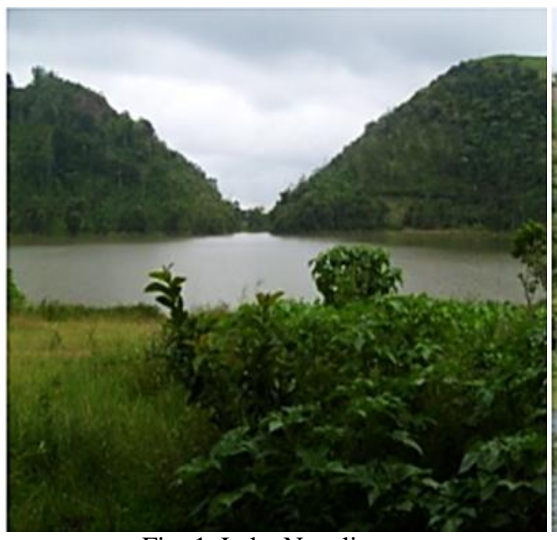

Fig. 1. Lake Napalit.

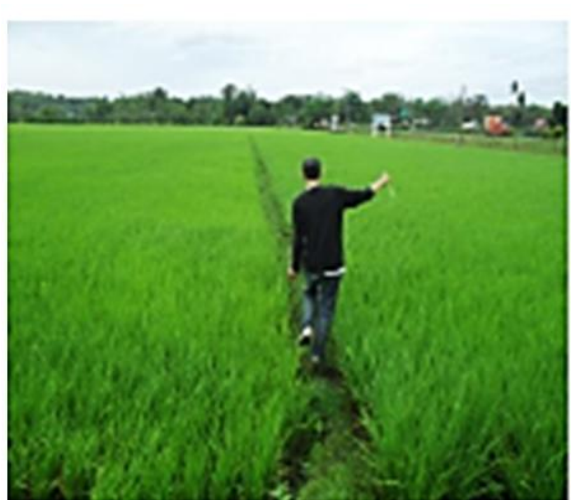

Fig. 4. CMU PhilRice

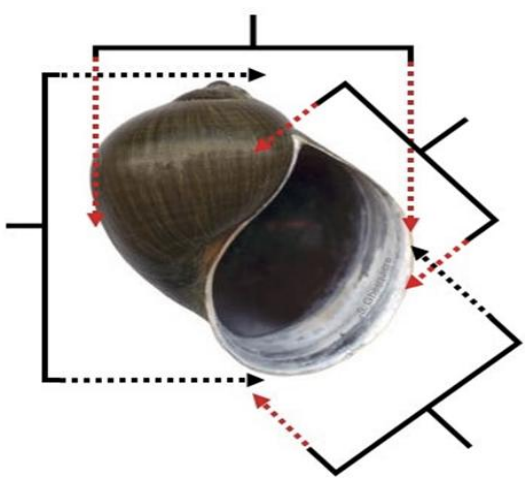

Fig. 7. Measuring aperture width.

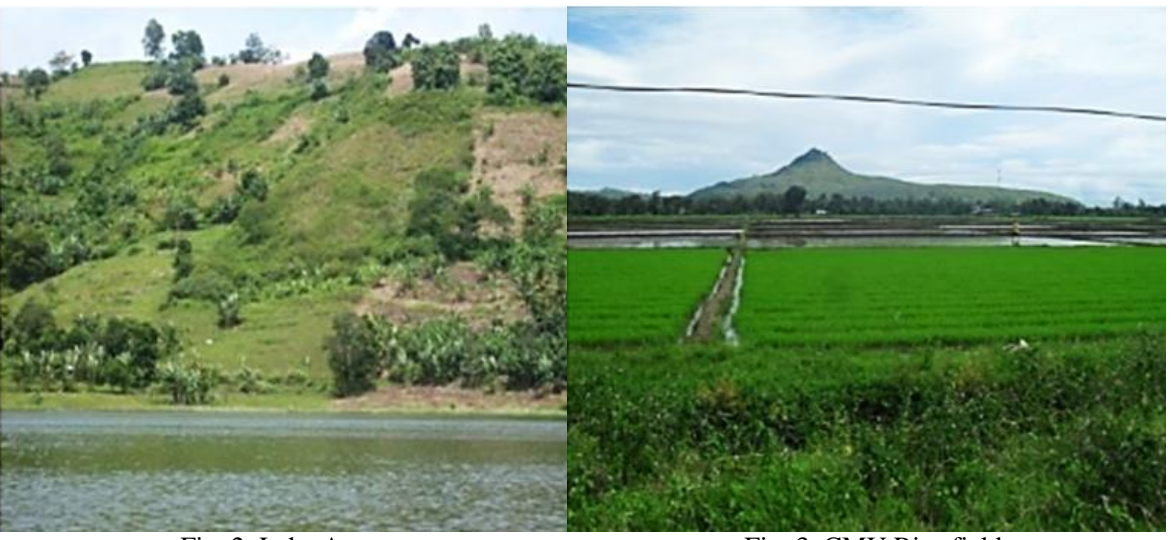

Fig. 2. Lake Apo.

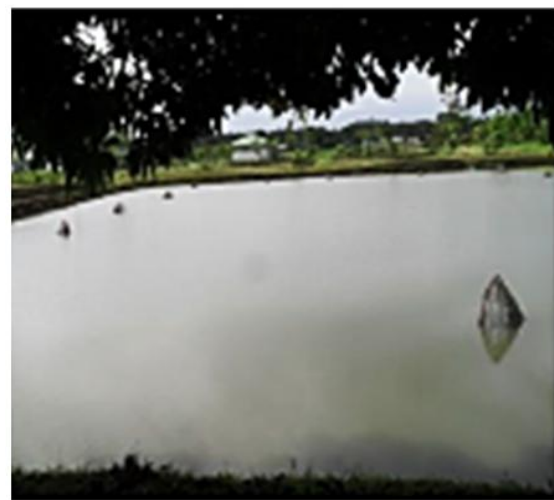

Fig. 5. CMU Fishpond.

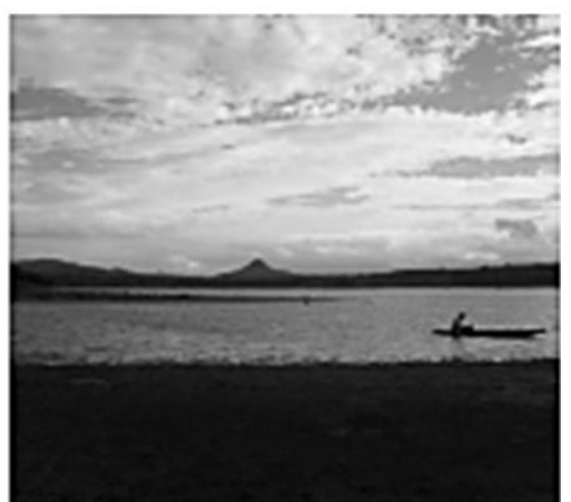

Fig. 6. Pulangui Lake.

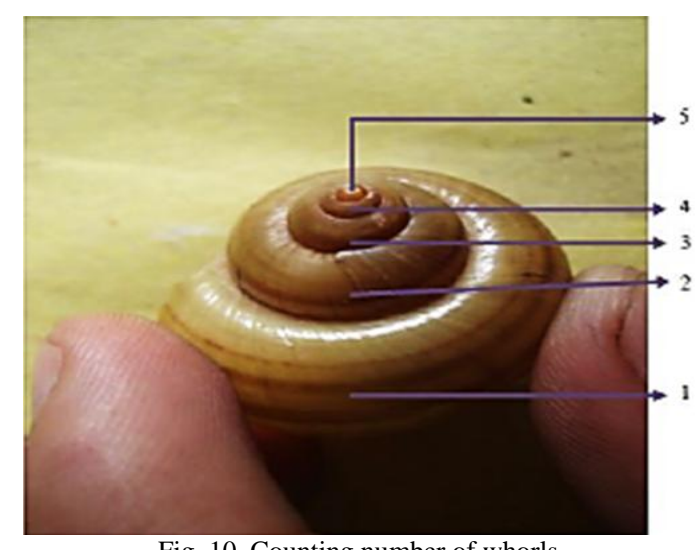

Fig. 10. Counting number of whorls.

III. RESULTS

Mean data for the weight, shell measurements and

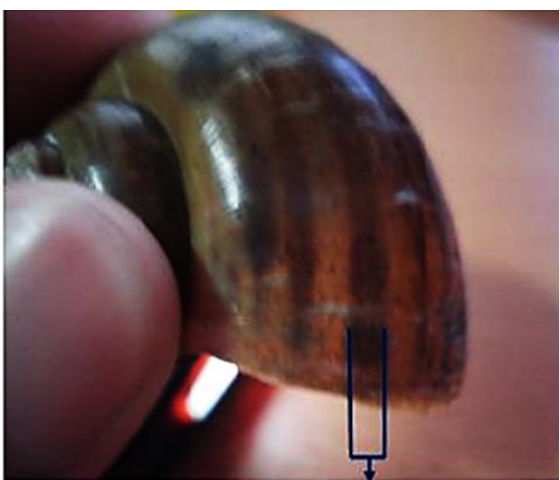

Fig. 8. Measuring band width.

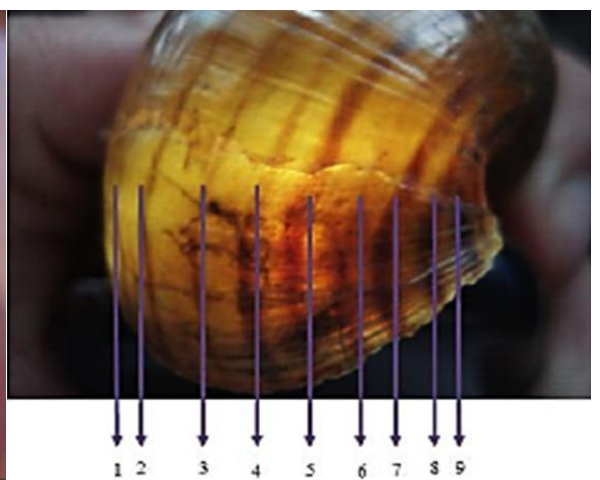

Fig. 9. Counting number of bands. physico-chemical parameters are given in Table I. Highest mean for weight and length were observed for the Pulangi collections. For aperture size and band width, the mean values for Lake Apo collections were higher than those of the other sites. But for the means in the number of bands and whorls, highest figures were from CMU fishpond and CMU rice fields samples, respectively. One remarkable feature observed was the presence of some discontinuous bands in some shells.

Pearson correlation analysis (Table II and Fig. 11) on the conchological features and physico-chemical parameters indicates that the variation in the number of bands and the average band width are significantly correlated only with depth. For the number of bands, a negative ( $r=-.973, P=.01)$ correlation appears with depth while for the band width, correlation with the said environmental factor is positive ( $r=.892, P=.05)$. 


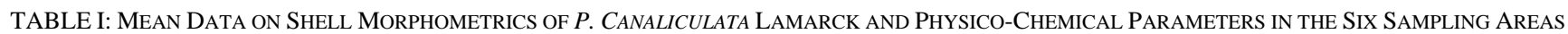
at Two SAMPLing Visits Per Site fOR THe Period of June, 2010 to FEBruary 2011

\begin{tabular}{|c|c|c|c|c|c|c|c|c|c|c|c|}
\hline \multicolumn{7}{|c|}{ MEAN MORPHOMETRIC DATA ON THE SIX SAMPLING AREAS } & \multicolumn{5}{|c|}{$\begin{array}{l}\text { PHYSICO-CHEMICAL PARAMETERS } \\
\text { (MEAN VALUES) }\end{array}$} \\
\hline & $\begin{array}{l}5 \\
0 \\
0 \\
3 \\
3\end{array}$ & 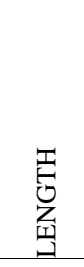 & 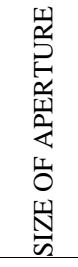 & \multirow{2}{*}{$\begin{array}{l}n \\
\hat{Z} \\
\infty \\
\infty \\
0 \\
0 \\
0 \\
\vdots\end{array}$} & \multirow{2}{*}{ 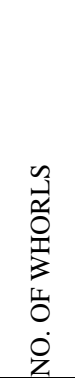 } & \multirow{2}{*}{ 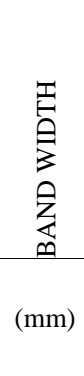 } & \multirow{2}{*}{$\begin{array}{l}\text { II } \\
\text { (m) } \\
\text { 牙 } \\
\text { (m }\end{array}$} & \multirow[t]{2}{*}{$\frac{\pi}{2}$} & \multirow{2}{*}{ 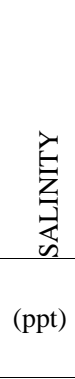 } & \multirow{2}{*}{ 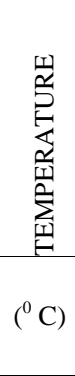 } & \multirow{2}{*}{$\begin{array}{c}\stackrel{\bigcirc}{0} \\
(\mathrm{mg} / \mathrm{L})\end{array}$} \\
\hline & (g) & $(\mathrm{mm})$ & $(\mathrm{mm})$ & & & & & & & & \\
\hline NAPALIT LAKE & 0.98 & 26.33 & 21.8 & 10.97 & 2.92 & 0.98 & 4.13 & 7.8 & 0.6 & 26.8 & 7.8 \\
\hline PULANGUI LAKE & 3.51 & 37.48 & 22.62 & 10.62 & 2.98 & 0.99 & 3.7 & 7.5 & 0.25 & 30.5 & 7.95 \\
\hline LAKE APO & 1.5 & 33.76 & 24.94 & 8.58 & 3.05 & 1.36 & 7.6 & 7 & 1.002 & 29.4 & 7.4 \\
\hline CMU FISHPOND & 1.72 & 36.22 & 20.27 & 11.81 & 4.02 & 0.89 & 2.81 & 7 & 1 & 27.7 & 9.9 \\
\hline CMU PHILRICE & 1.472 & 31.17 & 17.07 & 11.2 & 4.025 & 0.95 & 3 & 7 & 1 & 28 & 8.6 \\
\hline CMU RICEFIELD & 1.73 & 36.09 & 20.22 & 11.26 & 4.04 & 0.74 & 3.5 & 7 & 1 & 27.3 & 7.4 \\
\hline
\end{tabular}

TABLE II: CORRELATION BETWEEN CONCHOLOGICAL CHARACTERS (APERTURE, BANDS AND WHORLS) AND PHYSICO-CHEMICAL PARAMETERS

\begin{tabular}{|l|l|l|l|l|l|}
\hline & DEPTH & $\mathrm{pH}$ & SALINITY & TEMPERATURE & \multicolumn{1}{|c|}{ DO } \\
\hline APERTURE & .804 & .271 & -.322 & .491 & -.478 \\
Sig.(2-tailed) & .054 & .603 & .534 & .322 & .338 \\
& 6 & 6 & 6 & 6 & 6 \\
\hline NO. OF BANDS & $\mathbf{- . 9 7 3 * *}$ & .064 & -.005 & -.544 & .605 \\
Sig.(2-tailed) & .001 & .904 & .993 & .265 & .204 \\
& 6 & 6 & 6 & 6 & 6 \\
\hline NO. OF WHORLS & -.581 & -.731 & .691 & -.446 & .501 \\
Sig.(2-tailed) & .227 & .099 & .128 & .375 & .311 \\
& 6 & 6 & 6 & 6 & 6 \\
\hline BAND WIDTH & $\mathbf{. 8 9 2 *}$ & -.020 & .013 & .514 & -.280 \\
Sig.(2-tailed) & .017 & .970 & .980 & .297 & .591 \\
& 6 & 6 & 6 & 6 & 6 \\
\hline
\end{tabular}

- Significant at 0.01 (level) - **

- Significant at 0.05 (level) - *

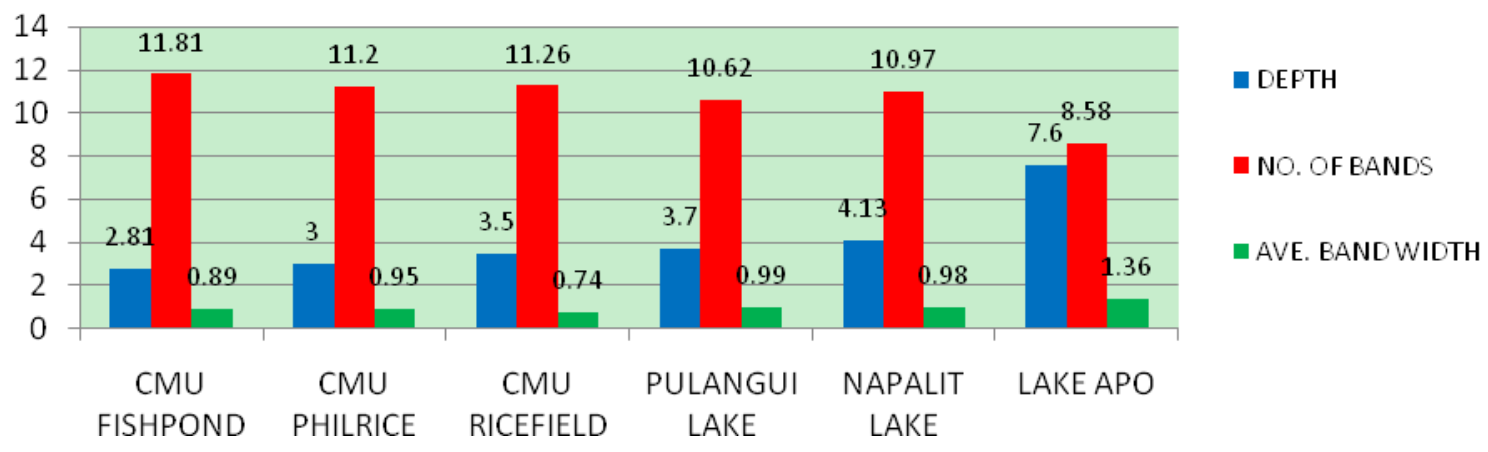

Fig. 11. Mean values for water depth and number of bands and average band width.

\section{DISCUSSION}

The data obtained in this study appear to link water depth to shell band number and band width. As indicated in the Pearson's correlation analysis, increase in water depth has $97 \%$ influence on the decrease in the average band number. At the same time, increase in the said factor has $89 \%$ influence on the increase in band width. While data in this study may add to existing information on relationships between environment and the development of conchological characters that are reported in literature, basic questions on the mechanisms involved remain unanswered. The study showing that polyenespresent in the colored parts of the shell and even more concentrated in parts with higher colour saturation is a useful lead on the existence of shell bands in general [12]. The same report however recognizes also the role of proteins and carbohydrates shown by earlier investigators in forming the outer shell matrix. Moreover, the neurosecretory model of shell growth and pattern formation and the recognition that shell growth and pig mentation involves neurosecretory activity of the mantle could help elucidate not only the regularity of shell design but also its alteration when there is environmental disturbance [13]. This idea could help explain why some shell bands in some individuals were discontinuous.

In the light of this information it is probable that the influence of the variation in water depth on shell band no. and average band width may have operated by way of this neurosecretory pathways in the golden apple snail. The possibility however that the other environmental factors may also exert influence cannot be ruled out. This is because neurosecretory activities are known to operate along 
threshold levels. For $P$. canaliculata, it is probable that variations in the other factors have not yet attained the required threshold for the species. However, this could be resolved in further investigations.

\section{CONCLUSION}

Among the relationships studied only that between water depth to average band width and the number of bands was established with the former showing a negative influence onthe variation onnumber of bands and a positive influenceon the average band width in $P$. canaliculata.

\section{ACKNOWLEDGEMENT}

The authors are grateful to the financial support of Central Mindanao University during the duration of the study. Likewise, they are thankful to the community covered by the study for their warm welcome and consent to this activity. To the colleagues of the Biology Department, their gratitude is also extended. A special mention of gratitude to Dr. R. Cowie for sharing important references.

\section{REFERENCES}

[1] Global Invasive Species Database. (2005). Pomacea canaliculata (mollusc). [Online].

Available: http://www.issg.org/database/species/ecology.asp?si=135

[2] R. C. Joshi, M. S. Delacruz, E. C. Martin et al., "Current status of the golden apple snail in the Ifugao rice Terraces, Philippines," Journal of Sustainable Agriculture Journal, vol. 18, no. 2-3, pp. 71-90, 2001.

[3] R. H. Cowie. (2005). Invasive apple snails (Ampullariidae) in Hawai and Southeast Asia. Center for Conservation Research and Training, University of Hawaii American Malacological Society. [Online]. Available: http://www.malacological.org/meetings/archives/2004/

[4] M. E. Seuffert, L. Saveanu, and P. R. Martin. (2012). Threshold Temperatures and Degree-Day Estimates for Embryonic Development of the Invasive Apple Snail Pomacea canaliculata (Caenogastropoda: Ampullariidae) Malacologia [Online]. 55(2). pp. 209-217. http://www.biome.org/doi/abs/104002/040.055.0203

[5] K. A. Hayes, R. H. Cowie, S. C. Thiengo, and E. E. Strong, "Comparing apples with apples: clarifying the identities of two highly invasive Neotropical Ampullariidae (Caenogastropoda)," Zoological Journal of the Linnean Society, vol. 166, pp. 723-753, 2012.

[6] R. H. Cowie, "Shell pattern polymorphism in a 13-year study of the Land Snail Thebapisana (Muller) (Pulmonata: Helicidae)," Malacologia, vol. 34, no. 1-2, pp. 87-97, 1992.

[7] M. A. J. Torres, L. R. T. Amarillo, R. Joshi, L. Sebastian, Z. Baoanan, and A. G. Demayo, "Intra- and Inter-Population Variability in the Golden Apple Snail Pomacea canaliculata," Australian Journal of Basic and Applied Sciences, vol. 5, no. 6, pp. 789-800, 2011.

[8] D. V. Nica, M. Bura, I. Gergen, M. Harmanescu, and B. DespinaMaria, "Bioaccumulative and conchological assessment of heavy metal transfer in a soil-plant-snail food chain," Chemistry Central Journal, vol. 6, no. 55, 2012.

[9] S. J. Preston, A. Harrison, M. Lundy, D. Roberts et al., "Square pegs in round holes-the implications of shell shape variation on the translocation of adult Margaritiferamargaritifera (L.). Aquatic conservation: Marine and freshwater ecosystems," Research and Development Series, vol. 20, pp. 568-573, Northern Ireland Environment Agency, 2010.

[10] M. Urabe, "Contributions of genetic and environmental factors to shell shape variation in the lotic snail Semisulcospirareiniana (Prosobranchia:Plueroceridae)," Journal of Molluscan Studies, vol. 64, no. 63, pp. 329-343, 1998.
[11] A. L. Estebenet, P. R. Martín, and S. Burela, "Conchological variation in Pomaceacanaliculata and other South American Ampullariidae (Caenogastropoda, Architaenioglossa)," Universidad Nacional del Sur, Departamento de Biologia, Bioquinica y Farmacia, San Juan 670, 800 Bahia Blanca, Argentina. ISSN 0327-9545, vol. 30, no. 2, 2006

[12] C. Hedegaard, J.-F. Bardeau, and D. Chateigner, "MolluscanShell Pigments: An in Situ resonance Raman study," Journal of Molluscan Studies, vol. 72, issue 2, pp. 157-162, August 2005.

[13] A. Boettiger, B. Ermentrout, and G. Oster, February, "The neural origins of shell structure and pattern in aquatic mollusk," Proceedings of the National Academy of Science of the United States, 2009.

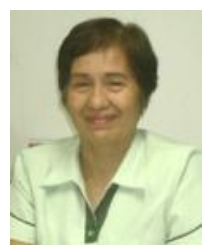

Gloria L. Galan was born in Nueva Estrella, Socorro, Surigao del Norte on November 5, 1952. She finished her bachelor of science in biology at the University of San Carlos, Cebu City, Philippines on May, 1974 and M.S. degree in biology in June 2013 at Central Mindanao University, Musuan, Bukidnon, Philippines. She has been teaching both the basic and major biology courses particularly invertebrate zoology, zoogeography, phycology, and comparative vertebrate anatomy at Central Mindanao University since July 1976. She was trained as an aquaculturist in 1991 (Tilapia and Catfish Culture and Hatchery) but later interest had been glared towards malacology. She had done researches and training on the culture and identification of freshwater and identification of freshwater and marine molluscs.

She is a member of some organizations like: Philippine Society of Biochemistry and Molecular Biology (PSBMB); Philippine Association of Institution for Research (PAIR); Asian Conference of Academic Journal and Higher Education Research (IAMURE); Philippine Society for the Advancement of Genetics, Inc. (PhilSAGen); Biology Teachers' Association (BIOTA); Malacological Society of the Philippines (MSPLifetime Member) and University Alumni Association at Central Mindanao University Faculty Association, Inc. (CMUFAI).

Recently, she is the project leader of the research on "Assessment diversity an management initiatives on molluscan fauna in Bucas Grande Island, Surigao del Norte, Philippines and study leader on "Molluscs in Bucas Grande Island, Surigao del Norte".

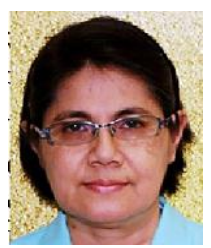

Heidi C. Porquis was born on November 26, 1954 in Bonifacio Misamis Occidental, Philippines. She holds a bachelor of science degree from Silliman University, Dumaguete City, and a master degree of science in biology from Central Mindanao University, Bukidnon, Philippines.

She is currently serving in the Faculty of the Biology Department to teach basic and major courses in biology particularly genetics, ecology, microtechnique and radiation biology. In addition to teaching, she is also assigned to the research and extension activities of the department. She is currently involved in two research projects one on drug discovery (The Tuklas Lunas) and the other on assessment of Molluscan fauna in Bucas Grande Island as a study leader and collaborator respectively. She has also presented scientific posters in local, national and international conferences, and co-authored instructional materials used in the Biology Department

She is a member of the Biology Teachers' Association (BIOTA) of the Philippines, Malacological Society of the Philippines, the Wildlife Conservation Society of the Philippines (WCSP), the PhilSAGen, the Silliman University Alumni Association, the Central Mindanao University Alumni Association and the Central Mindanao University Faculty Association, Inc.

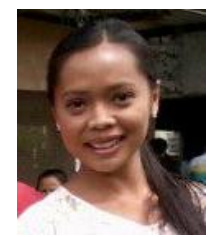

Mae Ann R. Bulasa has got her B.S. degree in biology. She worked as a research assistant in this CMU-funded project (Shell Band Pattern of Golden Apple (Pomacea canaliculata, Lamarck) in Selected Aquatics Habitats. 